\title{
Factors Motivating Female Entrepreneurs: A Study Conducted in Major Urban Area of Punjab
}

Sidra Saeed

M. Phil Scholar, Department of Sociology, G.C University Faisalabad, Pakistan

Naazia Malik

Assistant Professor, Department of Sociology, G.C University Faisalabad, Pakistan

Malik Muhammad Sohail

M. Phil Scholar, Department of Sociology, G.C University Faisalabad, Pakistan

Aqeela Tabassum

District Demographer, Population Welfare Department, Chakwal, Pakistan

Haq Nawaz Anwar

Chairman, Department of Sociology, Government College University, Faisalabad, Pakistan

Doi:10.5901/mjss.2014.v5n4p669

\begin{abstract}
Female entrepreneurship is a prominent element of economy today. It is the way to job creation that can contribute to personal development simultaneously. It is efficiently dealing with numerous economic and social problems all over the world. Economic disparity and unemployment are central issues to Pakistan in this decade. Entrepreneurship is a virtue that is capable of removing all the vices associated with economic growth, social disparities and employment. The main aim of the study was to explore the social, cultural and economic implications of female entrepreneurship and identify the causes and motivational factors, obstacles and gender discrimination. Snowball sampling technique was used in this study. Data were collected from 120 female entrepreneurs. For data collection interview schedule was used. The result reveals that majority females entrepreneurs started their business to contribute to family income and personal interest. Male member's permission is necessary for running a business. These results indicate the male dominance in society. Statistical analysis shows a significant association between education of the respondents and their participation level in entrepreneurship. It means education level of the respondents positively associated with their participation level in entrepreneurship.
\end{abstract}

Keywords: Female Entrepreneurship, Motivation, Causes, Lahore.

\section{Introduction}

Female entrepreneurship is a prominent element of economy today. In order to attain its competitive position in dynamic economy it is important to gain knowledge about all aspects of female entrepreneurship. Female entrepreneurship seems to be the motivating vigor to achieve economic growth. It is the way to job creation that can contribute to personal development simultaneously. It is efficiently dealing with numerous economic and social problems all over the world (Sarri and Trihopoulou, 2004). In the last two decades, many Western-European countries have eye witnessed an augment in female entrepreneurship as a result of cultural, political and economic change (OECD, 1997). In some countries, there are a lot of facts available that prove women behave in a different way to what one would expect (Duncan, 1991) because of different cultural values. Cultural values and traditional customs determine the level of liberty of an individual in many societies.

Entrepreneurship is a desirable quality that is able of abolishing all the vices related to economic augmentation, social disparities and employment. Many countries of the world are actively seeking ways and means to promote 
entrepreneurship. The important role of female entrepreneurs cannot be denied in several developing countries where these entrepreneurs are playing significant role to help their governments. The importance of SMEs reveals the dire need to provide employment. There is need to increase economic growth and produce extra capital for large-scale operations in countries which are not well developed (Hailey, 1987). Female entrepreneurship helps the process of economic development, creation of new jobs, and cut back unemployment in rural areas. It also helps to reduce migration. Female entrepreneurs have exhibited that they can handle small scale projects in all over the world. Entrepreneurial activities are restricted and imperfect in Pakistan. A survey by World Bank has measured entrepreneurial activities in 84 developing and industrial countries during 2003-2005. Average entry rate in Pakistan, calculated as new registrations of companies annually (as a percentage) registered businesses was 7 percent. This is lower than many of the regional averages worldwide (Mahmood et al., 2012).

Low entrepreneurial activity in Pakistan is problematic that need attention of government and business sector. Small business is playing an important role in economy of Pakistan. Large-scale activities are dominant in manufacturing output while SMEs provide the excessive employment. Enterprises with less than 100 employed individuals are almost 90 percent of all private enterprises in the industrial sector. SMEs employ some $78 \%$ of the labor force that is nonagriculture. SMEs are contributing over $30 \%$ to GDP, $25 \%$ of earnings from manufacturing export, and $35 \%$ in manufacturing value added. Maximum SMEs are producing low value-added products that rely on traditional technologies even though they produce a quarter of manufacturing exports (Chemin, 2007).

\subsection{The Business Environment for Women Entrepreneurs in Pakistan}

Female entrepreneurs do not work in separate environment. They work in same macro, regulatory and institutional framework where males of this society work. It must be understood that the level of gender biasness deeply rooted in society restricts the females' mobility. Gender biasness hinders interactions of females, their active economic contribution and opportunity to business development services. Unfortunately females completely lack freedom of speech (Goheer, 2003). The business atmosphere for women reflects the complex interplay of many factors that can be divided into two basic categories. The first Category comprises of social, cultural, traditional and religious elements. This aspect of the society is formed over many centuries. It is fixed in the patriarchal structure and clearly established in the women's lower status. The gender prejudice of such a system is inflexible and deep-rooted because its legitimacy is drawn from the continuation of a traditional mind-set, recognized rituals and a firm belief in this system.

The second category of factors is drawn from the first group. This category involves constitutional structures, policy documents, regulatory arrangements and institutional mechanisms. It is contemporary not traditional so it is unbiased. The traditional systems create difficulties for women in general and entrepreneurs in particular in two ways. First, they are discriminatory inherently. Second, they constrain the equity-based composition of modern institutions and their fair working, as modern institutions are derived from traditional ones.

Objectives of this study are; to explore the demographic characteristics of female entrepreneurs in Pakistan and to check out the extent of influence for social implications on female entrepreneurs in Pakistan.

\section{Materials and Methods}

The research methodology is a systematic way that is proposed to solve the research problem. The objective of this research is to gain knowledge about Pakistani women entrepreneurs. This survey is designed on quantitative bases to explore the social, cultural and economic factors responsible for the female entrepreneurship. The study was conducted in Lahore. It is located in the east of the Punjab province as well the capital, in Pakistan. It is the second largest city of Pakistan. Lahore has been a midpoint of cultural tradition for many societies. A representative sample of population was selected from Lahore city of province Punjab, Pakistan. Female entrepreneurs are selected from urban areas of Lahore. The total sample size for the present study consisted of 120 female entrepreneurs. Respondents were chosen from urban areas of Lahore. Interview schedule was used for the purpose of data collection. Interview schedule was prepared in English and then translated into Urdu language for taking the information. The interview schedule consisted of all close ended questions. Interview schedule was used for both literate and illiterate respondents.

\section{Results and Discussions}

Data analysis is application of methods to describe facts explored by a research. It helps to detect patterns of data and 
researchers develop further explanations from data analysis. It is also needed for hypotheses testing. It is used in business, in administration, and in policy.

Table 1: Demographic Features of Female Entrepreneurs

\begin{tabular}{|c|c|c|}
\hline Age Group & Frequency $(f)$ & Percentage \\
\hline under 20 & 5 & $4.2 \%$ \\
\hline 21 to 30 & 34 & $28.3 \%$ \\
\hline 31 to 40 & 44 & $36.7 \%$ \\
\hline above 40 & 37 & $30.8 \%$ \\
\hline \multicolumn{3}{|l|}{ Marital Status } \\
\hline Single & 34 & $28.3 \%$ \\
\hline Married & 75 & $62.5 \%$ \\
\hline Widow & 8 & $6.7 \%$ \\
\hline Other & 3 & $2.5 \%$ \\
\hline \multicolumn{3}{|l|}{ Education } \\
\hline \multicolumn{3}{|l|}{ Business type } \\
\hline Boutique & 26 & $21.7 \%$ \\
\hline Garments & 29 & $24.2 \%$ \\
\hline Shopkeeper & 12 & $10.0 \%$ \\
\hline beauty salon & 14 & $11.7 \%$ \\
\hline Jewelry & 16 & $13.3 \%$ \\
\hline Other & 23 & $19.2 \%$ \\
\hline \multicolumn{3}{|c|}{ Business experience } \\
\hline up to 1 & 14 & $11.7 \%$ \\
\hline 1 to 3 & 28 & $23.3 \%$ \\
\hline 4 to 6 & 26 & $21.7 \%$ \\
\hline above 6 & 52 & $43.3 \%$ \\
\hline \multicolumn{3}{|l|}{ Monthly income } \\
\hline up to 10 & 29 & $24.2 \%$ \\
\hline 11 to20 & 37 & $30.8 \%$ \\
\hline 21 to 30 & 34 & $28.3 \%$ \\
\hline above 30 & 20 & $16.7 \%$ \\
\hline \multicolumn{3}{|l|}{ Breadwinner } \\
\hline Husband & 58 & $48.3 \%$ \\
\hline Brother & 1 & $.8 \%$ \\
\hline Father & 26 & $21.7 \%$ \\
\hline You & 35 & $29.2 \%$ \\
\hline \multicolumn{3}{|l|}{ No of children } \\
\hline None & 33 & $27.5 \%$ \\
\hline 1 to 3 & 36 & $30.0 \%$ \\
\hline 4 or 5 & 34 & $28.3 \%$ \\
\hline Above 5 & 17 & $14.2 \%$ \\
\hline \multicolumn{3}{|l|}{ Type of family } \\
\hline Nuclear & 64 & $53.3 \%$ \\
\hline Joint & 50 & $41.7 \%$ \\
\hline Extended & 5 & $4.2 \%$ \\
\hline Other & 1 & $.8 \%$ \\
\hline \multicolumn{3}{|l|}{ Type of housing } \\
\hline Own & 77 & $64.2 \%$ \\
\hline Rent & 43 & $35.8 \%$ \\
\hline Total & 120 & 100.0 \\
\hline
\end{tabular}

Table 1 show that a majority of the respondents $36.7 \%$ were between 31 to 40 years old. $4.2 \%$ were in the age group of under 20 years. Mostly female entrepreneurs were older. In Pakistan, young females don't choose business line due to male dominance. These findings indicate the evidence to confirm similar findings by previous researches (Sarri and 
Trihopoulou, 1997; Mahmood et al., 2012). Another research finding show those females were young (Yilmaz et al., 2012). Above table shows that $62.5 \%$ were married. $2.5 \%$ were in the other (divorced and separated). From the findings one can easily perceive that cultural and social restrictions are hurdle for single and young entrepreneurs. Findings of this study are supported by previous findings of (Vatharkar, 2012). It shows that 32.5\% were under matric and F.A. $10.8 \%$ was above graduation. The majority of females were uneducated. In Pakistan, still level of education is very poor. Education do not consider necessary for females. In Pakistan, females participation is negligible and discourage the females participation in all sectors. $24.2 \%$ respondents were run garments business. $10 \%$ were shopkeeper. Majority of females run boutique and ladies garments business. They avoid interaction with males because dealing with men is not considered worthy. Table also shows that $43.3 \%$ respondents' business experience was above $6.11 .7 \%$ respondents' business experience was up to 1 . The vast majority of females have lot of experience. They successfully run their business due to the lot of experience. Findings of this study are supported by previous findings of (Vatharkar, 2012). By the dint of lot of experience, females gain more respect in the market. It shows that $30.8 \%$ respondents' monthly income was 11 to $20.16 .7 \%$ respondents' monthly income was above 30 . Table shows that $48.3 \%$ respondents told that breadwinner were husband. $.8 \%$ was brother. We lived in male dominant society. In our society, income of female is a matter of dishonor for the family. Table also shows that $30.0 \%$ respondents had 1 to 3 children. $14.2 \%$ replied that they had more than 5 children. Findings of this study are supported by previous findings of (Vatharkar, 2012).

Table shows that $53.3 \%$ respondents were from nuclear family. $4.2 \%$ were from extended. Findings of this study are supported by previous findings of (Vatharkar, 2012).

Table 2: Causes and motivational factors behind their business

\begin{tabular}{|c|c|c|c|c|c|c|}
\hline Statements & $\begin{array}{c}\text { To great } \\
\text { extent }\end{array}$ & $\begin{array}{c}\text { To some } \\
\text { extent }\end{array}$ & $\begin{array}{c}\text { Not at } \\
\text { all }\end{array}$ & $\begin{array}{l}\text { Don't } \\
\text { know }\end{array}$ & Mean & $\begin{array}{l}\text { Standard } \\
\text { deviation }\end{array}$ \\
\hline $\begin{array}{l}\text { You started your own business due to family } \\
\text { business background }\end{array}$ & $\begin{array}{c}13 \\
10.8 \% \\
\end{array}$ & $\begin{array}{c}11 \\
9.2 \% \\
\end{array}$ & $\begin{array}{c}96 \\
80.0 \% \\
\end{array}$ & $\begin{array}{c}0 \\
0 \% \\
\end{array}$ & 2.69 & .658 \\
\hline $\begin{array}{l}\text { You started your own business due to own } \\
\text { interest }\end{array}$ & $\begin{array}{c}58 \\
48.3 \% \\
\end{array}$ & $\begin{array}{c}21 \\
17.5 \%\end{array}$ & $\begin{array}{c}41 \\
34.2 \% \\
\end{array}$ & $\begin{array}{c}0 \\
0 \%\end{array}$ & 1.85 & .900 \\
\hline $\begin{array}{l}\text { You started your own business to attain self } \\
\text { confidence }\end{array}$ & $\begin{array}{c}40 \\
33.3 \% \\
\end{array}$ & $\begin{array}{c}28 \\
23.3 \% \\
\end{array}$ & $\begin{array}{c}52 \\
43.3 \% \\
\end{array}$ & $\begin{array}{c}0 \\
0 \% \\
0 \%\end{array}$ & 2.10 & .873 \\
\hline You started your own business to gain autonomy & $\begin{array}{c}27 \\
22.5 \% \\
\end{array}$ & $\begin{array}{c}23 \\
19.2 \% \\
\end{array}$ & $\begin{array}{c}70 \\
58.3 \% \\
\end{array}$ & $\begin{array}{c}0 \\
0 \% \\
0 \%\end{array}$ & 2.35 & .828 \\
\hline $\begin{array}{l}\text { You started your own business to contribute in } \\
\text { family income }\end{array}$ & $\begin{array}{c}62 \\
51.7 \% \\
\end{array}$ & $\begin{array}{c}26 \\
21.7 \% \\
\end{array}$ & $\begin{array}{c}32 \\
26.7 \% \\
\end{array}$ & $\begin{array}{c}0 \\
0 \% \\
0 \%\end{array}$ & 1.75 & .852 \\
\hline $\begin{array}{l}\text { You started your own business due to fear of } \\
\text { unemployment }\end{array}$ & $\begin{array}{c}14 \\
11.7 \%\end{array}$ & $\begin{array}{c}17 \\
14.2 \%\end{array}$ & $\begin{array}{c}89 \\
74.2 \%\end{array}$ & $\begin{array}{c}0 \\
0 \%\end{array}$ & 2.62 & 686 \\
\hline $\begin{array}{l}\text { Encouragement by family and friends motivated } \\
\text { you to start your own business }\end{array}$ & $\begin{array}{c}50 \\
41.7 \% \\
\end{array}$ & $\begin{array}{c}30 \\
25.0 \% \\
\end{array}$ & $\begin{array}{c}40 \\
33.3 \% \\
\end{array}$ & $\begin{array}{c}0 \\
0 \% \\
0 \%\end{array}$ & 1.91 & .865 \\
\hline you feel self satisfaction as female entrepreneur & $\begin{array}{c}95 \\
79.2 \%\end{array}$ & $\begin{array}{c}21 \\
17.5 \%\end{array}$ & $\begin{array}{c}4 \\
3.3 \%\end{array}$ & $\begin{array}{c}0 \\
0 \%\end{array}$ & 1.24 & .502 \\
\hline $\begin{array}{l}\text { You gain respect and social prestige after } \\
\text { starting your business }\end{array}$ & $\begin{array}{c}88 \\
73.3 \% \\
\end{array}$ & $\begin{array}{c}17 \\
14.2 \% \\
\end{array}$ & $\begin{array}{c}15 \\
12.5 \% \\
\end{array}$ & $\begin{array}{c}0 \\
0 \% \\
0 \%\end{array}$ & 1.39 & .701 \\
\hline $\begin{array}{l}\text { To what extent economic security give } \\
\text { satisfaction to you? }\end{array}$ & $\begin{array}{c}90 \\
75.0 \%\end{array}$ & $\begin{array}{c}28 \\
23.3 \%\end{array}$ & $\begin{array}{c}2 \\
1.7 \%\end{array}$ & $\begin{array}{c}0 \\
0 \%\end{array}$ & 1.26 & .480 \\
\hline $\begin{array}{l}\text { Did you have access to financial resources when } \\
\text { you started your business? }\end{array}$ & $\begin{array}{c}45 \\
37.5 \% \\
\end{array}$ & $\begin{array}{c}36 \\
30.0 \% \\
\end{array}$ & $\begin{array}{c}39 \\
32.5 \% \\
\end{array}$ & $\begin{array}{c}0 \\
0 \% \\
0 \%\end{array}$ & 1.95 & .838 \\
\hline $\begin{array}{l}\text { Did you have social capital when you started } \\
\text { your business }\end{array}$ & $\begin{array}{c}79 \\
65.8 \%\end{array}$ & $\begin{array}{c}32 \\
26.7 \%\end{array}$ & $\begin{array}{c}9 \\
7.5 \%\end{array}$ & $\begin{array}{c}0 \\
0 \%\end{array}$ & 1.41 & .629 \\
\hline
\end{tabular}

The objective of these questions was to investigate the causes and motivational factors behind female entrepreneurs. An enormous majority, $80.0 \%$ respondents told that they had no family business background. $9.2 \%$ told to some extent. $48.3 \%$ respondents told that they started their business due to own interest to great extent. $17.5 \%$ told to some extent. It means that a majority of respondents started their business due to their personal interest.

The next question is about self confidence of female entrepreneurs. $43.3 \%$ respondents said that they did not start their business to attain self confidence. Remaining $23.3 \%$ told 'to some extent'. It is evident from our research findings that a majority of $58.3 \%$ respondents told that they did not start their business to gain autonomy. $19.2 \%$ told to some 
extent. Majority, $51.7 \%$ respondents told that they started their business to contribute to family income to great extent. $21.7 \%$ told 'to some extent'.

A huge majority, $74.7 \%$ respondents asserted that they did not start their business due to fear of unemployment. $11.7 \%$ told 'to great extent'. $41.7 \%$ respondents told that family and friends encouraged them to great extent. $25.0 \%$ told to some extent. The huge majority, $79.2 \%$ respondents told that they feel self satisfaction to great extent. $3.3 \%$ told not at all. These findings reveal that a huge majority of female entrepreneurs feel self satisfaction.

The huge majority, $73.3 \%$ respondents told that to great extent they gain social respect in the society. $12.5 \%$ told not at all. In response to the question "To what extent economic security give satisfaction to you", huge majority, respondents replied that is $75.0 \%$ to great extent. $1.7 \%$ told not at all.

This portion contains questions about resources required to initiate a business. $37.5 \%$ respondents responded to great extent' that they had access to financial resources. $30.0 \%$ said 'to some extent'. A majority, $65.8 \%$ respondents told that they had social capital when they started their business. $7.5 \%$ told not at all.

Table 3: Female entrepreneurship

\begin{tabular}{|c|c|c|c|c|c|c|}
\hline Statements & To great extent & \begin{tabular}{|l|} 
To some extent \\
\end{tabular} & Not at all & Don't know & Mean & Standard deviation \\
\hline Are you satisfied with your business & $\begin{array}{c}65 \\
54.2 \%\end{array}$ & $\begin{array}{c}35 \\
29.2 \%\end{array}$ & $\begin{array}{c}20 \\
16.7 \%\end{array}$ & $\begin{array}{c}0 \\
0 \%\end{array}$ & 1.62 & .756 \\
\hline $\begin{array}{l}\text { Do you want to maintain your business } \\
\text { in future }\end{array}$ & $\begin{array}{c}79 \\
65.8 \%\end{array}$ & $\begin{array}{c}32 \\
26.7 \%\end{array}$ & $\begin{array}{c}9 \\
7.5 \%\end{array}$ & $\begin{array}{c}0 \\
0 \%\end{array}$ & 1.41 & .629 \\
\hline $\begin{array}{l}\text { Female should take part in business } \\
\text { endeavors }\end{array}$ & $\begin{array}{c}45 \\
37.5 \%\end{array}$ & $\begin{array}{c}57 \\
47.5 \%\end{array}$ & $\begin{array}{c}18 \\
15.0 \%\end{array}$ & $\begin{array}{c}0 \\
0 \%\end{array}$ & 1.77 & .691 \\
\hline Conditions are favorable for females & $\begin{array}{c}21 \\
17.5 \%\end{array}$ & $\begin{array}{c}42 \\
35.0 \%\end{array}$ & $\begin{array}{c}45 \\
37.5 \%\end{array}$ & $\begin{array}{c}12 \\
10.0 \%\end{array}$ & 2.40 & .892 \\
\hline You face restrictions from family? & $\begin{array}{c}23 \\
19.2 \%\end{array}$ & $\begin{array}{c}32 \\
26.7 \%\end{array}$ & $\begin{array}{c}65 \\
54.2 \%\end{array}$ & $\begin{array}{c}0 \\
0 \%\end{array}$ & 2.35 & .784 \\
\hline From where you feel more restriction? & & & & $\begin{array}{c}0 \\
0 \%\end{array}$ & 4.01 & 1.32 \\
\hline $\begin{array}{l}\text { To what extent you have your family } \\
\text { support? }\end{array}$ & $\begin{array}{c}84 \\
70.0 \% \\
\end{array}$ & $\begin{array}{c}28 \\
23.3 \% \\
\end{array}$ & $\begin{array}{c}8 \\
6.7 \% \\
\end{array}$ & $\begin{array}{c}0 \\
0 \% \\
0\end{array}$ & 1.36 & .607 \\
\hline From where you feel more support? & & & & $\begin{array}{c}0 \\
0 \%\end{array}$ & 2.28 & 1.37 \\
\hline
\end{tabular}

A Majority, 54.2\% respondents replied that they are satisfied with their business to great extent.16.7\% respondents told not at all. A huge majority, $65.8 \%$ respondents told that they want to maintain their business in future to great extent.7.5\% respondents told not at all. $47.5 \%$ respondents respond to some extent that females should take part in business endeavors. $15.0 \%$ respondents told not at all. $37.5 \%$ respondents replied that conditions are not favorable for females. In Pakistan, females don't have enough access to resources and technology, proper guidance, sufficient market knowledge. ILO report the major barriers to expanding women enterprises are a lack of affordable technology and training or low level of education. Yet attitudes, the psycho-social forces of the individual and the cultural context, are of prime importance in influencing entrepreneurial behavior patterns. More than half, $54.2 \%$ respondents told that they did not face restrictions from family. $19.2 \%$ told 'to great extent'. These results clearly show that a major shift has taken place in culture. Females are taking permissions for business conveniently. A huge majority, $70.0 \%$ respondents told to great extent. $6.7 \%$ told not at all.

\section{Testing of Hypotheses}

\subsection{Hypothesis 1: Education of the respondents will be influence on their participation in entrepreneurship}

Table 4: Association between education of the respondents and their participation level in entrepreneurship

\begin{tabular}{|c|c|c|c|c|}
\hline \multirow{2}{*}{ Education } & \multicolumn{3}{|c|}{ Female Entrepreneurship } & \multirow{2}{*}{ Total } \\
\cline { 2 - 4 } & Low & Medium & High & \\
\hline \multirow{2}{*}{ Under Matric } & 14 & 17 & 8 & 39 \\
\cline { 2 - 4 } & $35.9 \%$ & $43.6 \%$ & $50.5 \%$ & $100.0 \%$ \\
\hline
\end{tabular}




\begin{tabular}{|c|c|c|c|c|}
\hline \multirow{2}{*}{ F.A } & 5 & 14 & 20 & 39 \\
\cline { 2 - 5 } & $12.8 \%$ & $35.9 \%$ & $51.3 \%$ & $100.0 \%$ \\
\hline \multirow{2}{*}{ B.A } & 4 & 7 & 18 & 29 \\
\cline { 2 - 5 } & $13.8 \%$ & $24.1 \%$ & $62.1 \%$ & $100.0 \%$ \\
\hline \multirow{2}{*}{ Above Graduation } & 3 & 3 & 7 & 13 \\
\cline { 2 - 5 } & $23.1 \%$ & $23.1 \%$ & $53.8 \%$ & $100.0 \%$ \\
\hline \multirow{2}{*}{ Total } & 26 & 41 & 53 & 120 \\
\cline { 2 - 5 } & $21.7 \%$ & $34.2 \%$ & $44.2 \%$ & $100.0 \%$ \\
\hline
\end{tabular}

Chi-square $=14.38 ;$ d.f. $=6 ;$ Significance $=.027^{*} ;$ Gamma $=.224 ;{ }^{*}=$ Significant

Table 1 presents the association between education of the respondents and their participation level in entrepreneurship. Chi-square value shows a significant association between education of the respondents and their participation level in entrepreneurship. Gamma value shows a positive relationship between the variables. It means education level of the respondents positively associated with their participation level in entrepreneurship. Above table clearly shows that majority of the BA and above BA respondents had medium to high level of participation in entrepreneurship as compared to under matric and FA respondents. So the hypothesis "Education of the respondents will be influence on their participation in entrepreneurship" is accepted.

\subsection{Hypothesis 2: Working experience of the respondents will be influence on their participation in entrepreneurship}

Table 5: Association between working experience of the respondents and their participation in entrepreneurship

\begin{tabular}{|c|c|c|c|c|}
\hline \multirow{2}{*}{ Business experience (in years) } & \multicolumn{3}{|c|}{ Female Entrepreneurship } & \multirow{2}{*}{ Total } \\
\cline { 2 - 5 } & Low & Medium & High & \\
\hline \multirow{2}{*}{ up to 1} & 7 & 4 & 3 & 14 \\
\cline { 2 - 5 } & $50.0 \%$ & $28.6 \%$ & $21.4 \%$ & $100.0 \%$ \\
\hline \multirow{2}{*}{1 to 3 } & 4 & 11 & 13 & 28 \\
\cline { 2 - 5 } & $14.3 \%$ & $39.3 \%$ & $46.4 \%$ & $100.0 \%$ \\
\hline \multirow{2}{*}{4 to 6 } & 8 & 7 & 11 & 26 \\
\cline { 2 - 5 } & $30.8 \%$ & $26.9 \%$ & $42.3 \%$ & $100.0 \%$ \\
\hline \multirow{2}{*}{ above 6 } & 7 & 19 & 26 & 52 \\
\cline { 2 - 5 } & $13.5 \%$ & $36.5 \%$ & $50.0 \%$ & $100.0 \%$ \\
\hline \multirow{2}{*}{ Total } & 26 & 41 & 53 & 120 \\
\cline { 2 - 5 } & $21.7 \%$ & $34.2 \%$ & $44.2 \%$ & $100.0 \%$ \\
\hline
\end{tabular}

Chi-square $=13.53 ;$ d.f. $=6 ;$ Significance $=.038 *$ Gamma $=.182 ;{ }^{*}=$ Significant

Table 2 presents the association between business experience of the respondents and their participation in entrepreneurship. Chi-square value shows a significant association between business experience of the respondents and their participation in entrepreneurship. Gamma value shows a positive relationship between the variables. It means business experience is positively associated with their participation in entrepreneurship. Above table clearly shows that majority of those respondents who had up to one years experience had low (50.0\%) participation, while majority of the those respondents who had more than one years working experience had more participation in entrepreneurship. So the hypothesis "Working experience of the respondents will be influence on their participation in entrepreneurship.

\section{Multivariate Analysis}

Table 6: Multivariate Analysis

\begin{tabular}{|c|c|c|c|c|c|c||}
\hline \multirow{2}{*}{ Model } & \multirow{2}{*}{ Variables } & \multicolumn{2}{|c|}{ Unstandardized Coefficients } & Standardized Coefficients & \multirow{2}{*}{$\mathrm{T}$} & \multirow{2}{*}{ Sig. } \\
\cline { 3 - 6 } & & $\mathrm{B}$ & Std. Error & Beta & & \\
\hline 1 & (Constant) & .537 & .256 & & .098 & $.038^{\star}$ \\
\hline & Marital status & .0108 & .092 & .008 & .118 & $.906^{\mathrm{ns}}$ \\
\hline & Education & .294 & .060 & .378 & 4.919 & $.000^{\star \star}$ \\
\hline
\end{tabular}

a Dependent Variable: Female Entrepreneurship
$\mathrm{R}^{2}=.49$
F-value $=\mathbf{2 7 . 8 3}$
Sig. $=.000$

${ }^{*}=$ Highly Significant,${ }^{*}=$ Significant, NS $=$ Non-significant 
The value of R-Square is 0.49 . This shows that the 49 percent change in opinion about female entrepreneurship was explained by the four variables such as marital status, education, business experience and monthly income in the model. This shows that overall model is statistically significant. The overall significance of the model can also be judged by the F-test. The F-value is 27.83 which is significant at less than one percent level of significant. This too suggests that the model is highly significant.

\subsection{Impact of marital status}

The coefficient for this variable had a positive sign with the value of 0.0108 and is non-significant at $5 \%$ level of significance. It shows that the marital status has no impact on their opinion about female entrepreneurship.

\subsection{Impact of education}

The coefficient for this variable had a positive sign with the value of 0.294 and is significant at $1 \%$ level of significance. It shows that the education has positive impact on their perception about female entrepreneurship.

\section{Conclusions}

Entrepreneurship is an influential element in order for today's economy of knowledge to attain its competitive and dynamic character. It is the driving force for the achievement of economic development and job creation, contributing at the same time to personal development and effectively dealing with numerous pathogenic social phenomena. In Pakistan, females' participation in entrepreneurial activities is very low. Purpose of this study was to explore the social, cultural and economic implications of female entrepreneurship and indentify the causes and motivational factors, obstacles and gender discrimination. The study has revealed that females taking part in entrepreneurial activities in Pakistan are mostly married with low education level and with older age i.e., 31-49 years. In Pakistan, females engage in entrepreneurial activities due to some motivational factors and family hardships. Main motivation for female entrepreneurs to earn money for personal use, to contribute to family income, and for self satisfaction Women entrepreneurs face lots of problems to running a new business. Lack of finance is a big hamper for female entrepreneurs. Lack of managerial skills, lack of awareness and knowledge about banking and market are major issues in a way of female entrepreneurship. Females do not choose the business line by the dint of Gender related issues like, gender discrimination, age discrimination, harassment, unwanted letters and calls, etc. In Pakistan, business conditions are not favorable for females. Statistical analysis shows a significant association between business experience of the respondents and their opinion about female entrepreneurship. Result shows a significant association between monthly income of the respondents and their opinion about female entrepreneurship.

\section{References}

Chemin, M. (2007).The Impact of the Judiciary on Entrepreneurship: Evaluation of the Access to Justice Program in Pakistan. Journal of Public Economics, 93(1-2). pp. 93-104.

Duncan I (1991). An introduction to entrepreneurship. CMA Magzine, 65(9), pp. 32.

Goheer, N. A. (2003). Women entrepreneurs in Pakistan; How to improve their bargaining power, Geneva, International Labor Office, 2003, ISBN 92-2-113628-0.

Hailey, J. M. (1987). Entrepreneurs and Indigenous Business in the Pacific, PIDP, East West Centre, Honolulu, HI.

Mahmood, B., Khalid, S., Sohail, M. M., and Babak, I. (2012). Exploring the Motivation and Barriers in Way of Pakistani Female Entrepreneurs. British Journal of Education, Society \& Behavioral Science. 2(4), pp. 353-368.

OECD (1997), Entrepreneurship and SMEs in transitional economies, The Vise grad Conference, OECD Proceedings, Paris.

Sarri, K. and Trihopoulou, A. (2005) Female entrepreneurs' personal characteristics and motivation: a review of the Greek situation. Women in Management Review. Vol. 20 (1), pp. 24-36.

Vatharkar, P. (2012). A Study of Constraints and Motivating Factors for Indian Women Entrepreneurs in Small Scale Industries. The 2012 International Conference on Business and Management, 6 - 7 September 2012, Phuket - Thailand.

Yilmaz, E., Özdemir, G., and Oraman, Y (2012). Women entrepreneurs: Their problems and entrepreneurial ideas. African Journal of Business Management, 6(26), pp. 7896-7904. 